\title{
Strategi dan Solusi Layanan Bimbingan Konseling Di Masa Pandemi COVID-19
}

\author{
Yuni Chotimawati \\ Mahasiswa Pascasarjana
}

Program Studi Magsiter Pedagogi

Universitas Pancasakti Tegal Jawa Tengah, Indonesia

\begin{abstract}
Abstrak
Layanan bimbingan konseling merupakan bagian integral dari proses pendidikan pada satuan pendidikan. Meskipun secara daring, layanan bimbingan konseling tetap harus dilaksanakan pada masa Pandemi Covid-19.. Diperlukan strategi dan solusi supaya layanan bimbingan konseling tetap dapat berlangsung pada masa Pandemi Covid-19. Whatsapp merupakan media social yang telah dikenal dan digunakan oleh banyak orang di Indonesia. Fitur-fitur yang terdapat pada Whatsapp mendukung pelaksanaan layanan bimbingan konseling secara daring. Layanan bimbingan konseling dan kegiatan pendukung baik format klasikal, format kelompok, maupun format individu dapat dilaksanakan melalui media social Whatsapp. Layanan format klasikal dan format kelompok dapat dilaksanakan melalui salah satu fitur Whatsapp yaitu Whatsapp Messenger Group sedangkan layanan format individu dapat dilaksanakan melalui fitur Whatsapp Chat. Dalam penggunaan Whatsapp sebagai media layanan bimbingan konseling secara daring, pastinya juga tetap memiliki hambatan. Beberapa hambatan yang seringkali muncul adalah kendala sinyal yang tidak selalu lancar dan kuat, memory HP yang penuh karena banyaknya file yang diterima, kurangnya interaksi antara guru dan peserta didik, sulit untuk mengetahui keseriusan peserta didik, dan motivasi peserta didik yang kurang, fasilitas pendukung HP yang digunakan, dan sulit memahami materi yang diberikan. Namun terlepas dari semua hambatan yang mungkin terjadi, sebagai platform yang user friendly dan sangat populer di Indonesia bahkan di dunia, Whatsapp tetap dapat digunakan sebagai salah satu media strategi dan solusi layanan bimbingan konseling pada masa Pandemi Covid-19
\end{abstract}

Kata Kunci: Layanan Bimbingan Konseling, Pandemi Covid-19, Strategi dan Solusi

\begin{abstract}
Guidance and counseling service is an integral part of the educational process in the education unit. During the Covid-19 pandemic, strategies and solutions are needed so it can be carried out online. Whatsapp is a social media that has been widely known and used by many people in Indonesia. The features found on Whatsapp support the implementation of online guidance and counseling service including its supporting activities such as classical formats, group formats, and individual formats. Classical format and group format services can be carried out through one of Whatsapp features known as Whatsapp Messenger Group, while individual format services can be conducted through Whatsapp Chat. However, there are some obstacles faced in using Whatsapp as a medium for online guidance and counseling services. Some of the obstacles that often arise are unstable signal, insufficient memory on cellphone due to many files received, lack of interaction between teachers and students, difficulty to check the seriousness of students, lack of student motivation, lack of supporting devices, and difficulty to understand the material given. However, despite all the obstacles that may occur, as a user friendly platform and very popular in Indonesia and even in the world, Whatsapp can still be used as a strategic media and solution for guidance and counseling service during the Covid-19 Pandemic.
\end{abstract}

Keywords: Guidance and Counseling Service, Covid-19 Pandemic, Strategies and solutions 


\section{Pendahuluan}

Pandemi Covid-19 di Indonesia, dimulai ketika Presiden mengumumkan dua kasus pertama Covid-19-seorang ibu dan anak perempuannya-di Istana Jakarta pada 2 Maret 2020. Sementara di seluruh dunia, virus menyebar ke lebih 100 negara. WHO mengumumkan status pandemi global pada 11 Maret. Kasus Covid-19 menggulung, meningkat berkali-kali lipat dalam hitungan hari. Pemerintah baru menetapkan pandemi Covid-19 sebagai bencana nasional pada 13 April. Lebih dari sebulan sejak pengumuman WHO. Setelah setahun badan kesehatan dunia WHO menetapkan Covid-19 sebagai pandemi pada 11 Maret 2020, lebih dari 1,4 juta penduduk Indonesia terinfeksi, tak kurang dari 38 ribu meninggal (Katadata.co.id, 2021).

Pandemi Covid-19 telah berdampak pada berbagai sektor, tidak terkecuali sektor pendidikan. Sebagai salah satu upaya pencegahan penularan virus Covid-19, selain program $5 \mathrm{M}$ (Memakai masker, menjaga Jarak, mencuci tangan, menjauhi kerumunan, dan mengurangi mobilitas) maka Pemerintah juga mengeluarkan himbauan untuk Work From Home (WFH) dan School From Home (SFH). Pembelajaran yang sebelumnya dilaksanakan secara tatap muka atau luring di sekolah berubah menjadi pembelajaran daring atau online. Pembelajaran daring menjadi strategi dan solusi efektif untuk mengaktifkan kelas meski sekolah telah ditutup mengingat pembelajaran tatap muka memiliki resiko besar pada masa pandemi Covid-19 ini.

Proofer Lodge pernah mengatakan bahwa, life is education and education is life. Pernyataan tersebut jika dipahami secara tekstual berarti bahwa kehidupan adalah pendidikan dan pendidikan adalah kehidupan. Antara kehidupan dengan pendidikan dan sebaliknya hampir tidak dapat dibedakan dan saling tidak terpisah. Kedua pengertian (pendidikan dan kehidupan) menyatu dalam sebuah kerangka filosofis. Proses yang dijalankan dalam pendidikan tidak lain adalah proses bagi manusia dalam mengarungi samudera kehidupan, dan begitu pula sebaliknya (Sagala, 2013). Ini berarti sepanjang masih ada kehidupan, maka masih ada pendidikan. Pendidikan harus terus berlangsung bagaimanapun kondisi yang sedang terjadi dalam kehidupan, termasuk saat kondisi pandemic Covid-19 ini.

Menurut Pusat Pengembangan Profesi Pendidik Badan Pengembangan Sumber Daya Manusia Pendidikan dan Kebudayaan dan Penjaminan Mutu Pendidikan Kementrian Pendidikan dan Kebudayaan (2014) bahwa layanan bimbingan konseling yang merupakan bagian integral dari proses pendidikan pada satuan pendidikan, di luar penyelenggaraan mata pelajaran, muatan lokal, ataupun kegiatan ekstra kurikuler. Pelayanan bimbingan konseling menunjang proses pencapaian pada satuan pendidikan. Program pelayanan bimbingan konseling merupakan upaya pengembangan kepribadian peserta didik yang dilakukan melalui berbagai jenis layanan dan kegiatan pendukung bimbingan konseling. Diungkapkan oleh Sagala (2013), di berbagai kesempatan para guru yang tinggi dedikasinya tidak mempedulikan hambatan yang dihadapinya. Mereka abaikan kesulitan yang muncul atau dirasakan, yang penting tetap dapat memberikan pelayanan memadai pada tiap peserta didik yang berada di bawah tanggung jawabnya. Begitu 
pula Pandemi Covid-19 ini tidak seharusnya menjadi hambatan bagi Guru BK untuk tetap dapat memberikan layanan bimbingan konseling pada peserta didik yang dicintai dan dibanggakannya meskipun melalui daring menggunakan media social, sebagai strategi dan solusi layanan bimbingan konseling pada masa pandemi Covid-19 ini.

\section{Pembahasan}

Menurut Pusat Pengembangan Profesi Pendidik Badan Pengembangan Sumber Daya Manusia Pendidikan dan Kebudayaan dan Penjaminan Mutu Pendidikan Kementrian Pendidikan dan Kebudayaan (2014) bahwa layanan bimbingan konseling yang merupakan bagian integral dari proses pendidikan pada satuan pendidikan, di luar penyelenggaraan mata pelajaran, muatan lokal, ataupun kegiatan ekstra kurikuler. Pelayanan bimbingan konseling menunjang proses pencapaian pada satuan pendidikan. Program pelayanan bimbingan konseling merupakan upaya pengembangan kepribadian peserta didik yang dilakukan melalui berbagai jenis layanan dan kegiatan pendukung bimbingan konseling.

Berdasarkan studi dan riset data yang dihimpun oleh We Are Social pada tahun 2019 , pengguna media sosial di Indonesia sudah mencapai 150 juta orang. Hal ini dapat diartikan bahwa sekitar 57\% dari seluruh penduduk Indonesia sudah menggunakan berbagai media social. Salah satu media social yang sering digunakan penduduk Indonesia adalah Whatsapp atau WA. Dihimpun dari data We Are Social, telah tercatat bahwa $83 \%$ orang indonesia telah menggunakan media sosial Whatsapp. Ini artinya, dari 150 juta pengguna media sosial di Indonesia, sekitar 125 juta orang sudah menggunakan WhatsApp (Merdeka.Com, 2020), sehingga dapat disimpulkan bahwa Whatsapp merupakan media social yang telah dikenal dan digunakan oleh banyak orang di Indonesia. Media sosial WhatsApp saat ini telah banyak digunakan oleh berbagai kalangan terutama pelajar.

Anwar \& Riadi ( dalam Wiji Lestari, 2021) mendefinisikan WhatsApp sebagai aplikasi chatting yang bisa mengirim pesan teks, gambar, suara, lokasi dan juga video ke orang lain dengan menggunakan smartphone jenis apapun. Aplikasi WhatsApp Messenger biasanya menggunakan koneksi 3G/4G atau WiFi untuk komunikasi data.Pertimbangan lainnya bahwa Whatsapp merupakan media sosial chatting tanpa menggunakan biaya, namun cukup menggunakan koneksi internet saja. Media WhatsApp mempunyai beberapa kelebihan. Adapun beberapa kelebihan dari Media WhatsApp yakni penggunaan yang mudah, praktis, cepat hemat data internet, dan dapat diakses hanya dengan handphone, memiliki berbagai fitur yang dapat digunakan untuk berkomunikasi mendukung seperti adanya New Group, New Broadcast, WhatsApp Web, Starred Messages and Setting dengan bantuan layanan internet. Pilihan menu group yang dijadikan tempat berdiskusi guru dengan peserta didik maupun peserta didik dengan teman-temannya dalam 
memecahkan masalah, contohnya guru mengirimkan beberapa soal yang harus dipecahkan sesuai materi yang telah diberikan, berdiskusi, penyampaian materi oleh guru, contohnya dalam pelaksanaan pembelajaran guru dapat menyampaikan materi dengan cara mengirimkan video pengajaran, dengan bentuk foto maupun rekaman suara (Wiji Lestari, 2021).

Fitur-fitur yang tersedia pada platform Whatsapp adalah WhatsApp dapat mengirim File foto, video, langsung dari kamera, pengelola berkas, dan galeri. Audio dapat langsung merekam suara, pengelola berkas, audio, dapat mengirim lokasi pengguna Whatsapp, dan dapat mengirim kontak (mengirim detail kontak dari kontak telepon). Fitur lain yang terdapat di WhatsApp adalah View Contact, Avatar, tambah pintasan, Email Conversation, salin dan kutip, Emoji, cari, Telepon WhatsApp Call, WhatsApp Video Call: Laporan Baca, Blokir, Info, Status, Status Pesan, Broadcats dan Group Chat, Hemat Bandwidth, Hapus Pesan Ke Semua Orang, dan lain-lain. Fiturfitur yang terdapat pada Whatsapp mendukung pelaksanaan layanan bimbingan konseling secara daring. Semua pertimbangan tersebut di atas menjadikan Whatsapp sebagai media social yang layak dipilih sebagai media dalam memberikan layanan bimbingan konseling baik bidang pribadi, bidang social, bidang belajar, dan bidang karir.

Layanan bimbingan konseling dan kegiatan pendukung baik format klasikal, format kelompok, maupun format individu dapat dilaksanakan melalui media social Whatsapp. Layanan format klasikal dan format kelompok dapat dilaksanakan melalui salah satu fitur Whatsapp yaitu Whatsapp Messenger Group sedangkan layanan format individu dapat dilaksanakan melalui fitur Whatsapp Chat. Untuk layanan format klasikal, Guru BK terlebih dahulu membuat Whatsapp Grup Messenger sesuai kelas atau kelompok peserta didik bimbingannya lalu menambahkan atau add anggota. Melalui Whatsapp Grup Messenger, guru BK dapat berbagi materi layanan baik dalam bentuk file, gambar, video, dan lain lain.

Begitu pula saat akan melaksanakan layanan konseling kelompok atau bimbingan kelompok. Untuk layanan konseling kelompok dan layanan bimbingan kelompok, terlebih dahulu guru BK membuat Whatsapp Group Messenger bagi kelompok peserta didik, kemudian add atau menambahkan contact peserta didik yang menjadi anggota kelompok ke dalam Whatsapp Group Messenger. Kemudian guru BK dapat melaksanakan proses konseling kelompok atau bimbingan kelompok sesuai urutan dan langkah yang telah ditentukan. WhatsApp Group Messenger ini memudahkan guru BK dalam menyebarkan informasi dimana pesan atau informasi dapat diterima oleh peserta didik dalam waktu yang bersamaan. WhatsApp Messenger Group bermanfaat sebagai sarana diskusi efektif dan kolaboratif secara online antara guru dan peserta didik ataupun sesama peserta didik dimanapun berada, WhatsApp Messenger Group merupakan aplikasi gratis yang mudah digunakan, WhatsApp Messenger Group dapat digunakan untuk berbagi komentar, tulisan, gambar, video, suara, dan dokumen, WhatsApp Messenger Group memberikan kemudahan untuk menyebarluaskan pengumuman maupun mempublikasikan karya dalam grup, Informasi 
dan pengetahuan dapat dengan mudah dibuat dan disebarluaskan melalui berbagai fitur WhatsApp Messenger Group .

Kegiatan pendukung bimbingan konseling juga dapat dilaksanakan melalui Whatsapp. Kegiatan pendukung himpunan data, guru BK dapat menghimpun data menggunakan Google Form yang link-nya di-share pada peserta didik melalui Whatsapp Grup Messenger. Bagi peserta didik yang membutuhkan layanan konsultasi dan layanan konseling individu dapat menggunakan fitur Whatsapp Chat baik melalui tulisan ataupun Voice Note antara Guru BK dan peserta didik karena fitur tersebut dapat memfasilitasi chatting atau obrolan yang membutuhkan ruang yang lebih pribadi/private. Jika diperlukan, Guru BK juga dapat bertatap maya dengan peserta didik melalui fitur video call meskipun hanya dengan maksimal 8 peserta didik. Fitur video call juga dapat dimanfaatkan untuk kegiatan pendukung home visit atau kunjungan rumah, sebagai alternatif "berkunjung dan bertemu" dengan peserta didik dan orangtua atau wali peserta didik meski terbatas hanya secara virtual.

Whatsapp sebagai media layanan bimbingan konseling daring, pastinya juga memiliki hambatan. Beberapa hambatan yang seringkali muncul adalah kendala sinyal yang tidak selalu lancar dan kuat, memory HP yang penuh karena banyaknya file yang diterima, kurangnya interaksi antara guru dan peserta didik, sulit untuk mengetahui keseriusan peserta didik, dan motivasi peserta didik yang kurang, fasilitas pendukung HP yang digunakan, dan sulit memahami materi yang diberikan. Menurut Wiji Lestari (2021), Media WhatsApp juga memiliki kekurangan. Adapun beberapa kekurangannya yaitu peserta didik sulit untuk bisa fokus pada pembelajaran karena suasana rumah yang kurang kondusif, keterbatasan paket internet atau kuota internet yang menjadi penghubung dalam pembelajaran daring, banyak sekali orang tua yang juga mengeluhkan beberapa masalah yang dihadapi peserta didik dalam belajar dirumah yakni terlalu banyak tugas yang diberikan kepada peserta didik, kurangnya kemampuan berinteraksi dan pendidik cenderung sering memberikan tugas sehingga peserta didik merasa terbebani oleh tugastugas tersebut, fasilitas handphone yang dimiliki orang tua, mengharuskan peserta didik terlambat mengerjakan tugas serta tidak jarang pengerjaan tugas dilakukan oleh orang tua bukan oleh peserta didik.

\section{Simpulan}

Pendidikan harus terus berlangsung bagaimanapun kondisi yang sedang terjadi dalam kehidupan, termasuk saat kondisi pandemic Covid-19 ini. Pandemi Covid-19 ini tidak seharusnya menjadi hambatan bagi Guru BK untuk tetap dapat memberikan layanan bimbingan konseling pada peserta didik yang dicintai dan dibanggakannya meskipun melalui daring menggunakan media social, sebagai strategi dan solusi layanan bimbingan konseling pada masa pandemi Covid-19 ini. Pada masa Pandemi Covid-19 ini, layanan bimbingan konseling dan 
kegiatan pendukung baik format klasikal, format kelompok, maupun format individu dapat dilaksanakan secara daring salah satunya menggunakan media sosial Whatsapp.

Whatsapp merupakan media social yang telah dikenal dan digunakan oleh banyak orang di Indonesia. Pertimbangan lainnya bahwa Whatsapp merupakan media sosial chatting tanpa menggunakan biaya, namun cukup menggunakan koneksi internet saja. Berbagai macam fitur yang tersedia pada Whatsapp dapat dimanfaatkan untuk melaksanakan layanan dan kegiatan pendukung bimbingan konseling.

Dalam penggunaan Whatsapp sebagai media layanan bimbingan konseling secara daring, pastinya juga memiliki hambatan. Beberapa hambatan yang seringkali muncul adalah kendala sinyal yang tidak selalu lancar dan kuat, memory HP yang penuh karena banyaknya file yang diterima, kurangnya interaksi antara guru dan peserta didik, sulit untuk mengetahui keseriusan peserta didik, dan motivasi peserta didik yang kurang, fasilitas pendukung HP yang digunakan, dan sulit memahami materi yang diberikan. Namun terlepas dari semua hambatan yang mungkin terjadi, sebagai platform yang user friendly dan sangat populer di Indonesia bahkan di dunia, Whatsapp tetap dapat digunakan sebagai salah satu media strategi dan solusi layanan bimbingan konseling pada masa Pandemi Covid-19.

\section{Daftar Pustaka}

https://katadata.co.id/timredaksikatadata/analisisdata/604aca2ea4564/indonesia-setelahsetahun-pandemi (Diakses tanggal 25 Mei 2021)

https://www.merdeka.com/jatim/10-macam-media-sosial-yang-paling-sering-digunakan-olehorang-indonesia-kln.html (Diakses tanggal 25 Mei 2021)

Pusat Pengembangan Profesi Pendidik Badan Pengembangan Sumber Daya Manusia Pendidikan dan Kebudayaan dan Penjaminan Mutu Pendidikan Kementrian Pendidikan dan Kebudayaan (2014). Materi Pelatihan Guru Implementasi Kurikulum 2013 Tahun 2014, Bimbingan dan Konseling SMA/SMK

Sagala, Syaiful. 2013. Kemampuan Professional Guru Dan Tenaga Kependidikan. Bandung: Alfabeta Lestari, Wiji. 2021. Pemanfaatan Media Whatsapp sebagai Media Pembelajaran dalam Jaringan Masa Pandemi Covid-19 di Kelas VI Sekolah Dasar. Skripsi Program SarjanaPendidikan Guru Sekolah DasarJurusan Pendidikan Anak Usia Dini dan Dasar Fakultas Keguruan dan Ilmu Pendidikan 